\title{
Is Routine Measurement of Post-operative Hemoglobin and Electrolytes Necessary in Every Patient After Transurethral Resection of the Prostate?
}

\author{
Transüretral Prostat Rezeksiyonu Sonrası Her Hastada Postoperatif Hemoglobin ve \\ Elektrolitlerin Rutin Ölçümü Gerekli midir?
}

(1) Muhammad Hammad Ali Mithani, (1) Salman El Khalid, (1) Shariq Anis Khan, (1) Imran Sharif, (1) Adnan Siddiq Awan

The Kidney Centre Post Graduate Training Institute, Department of Urology, Karachi, Pakistan

What's known on the subject? and What does the study add?

Although subject is not new but little scientific evidence available, most urologists practice based on their preference and experience. Results will have positive impact on cost and other issues related to this subject.

\begin{abstract}
Objective: To evaluate the importance of post-operative hemoglobin and electrolyte monitoring after transurethral resection of the prostate (TURP) and establish the parameters to be considered for monitoring.

Materials and Methods: Data of patients who underwent TURP between 2007 and 2017 were reviewed. Data regarding prostate size, irrigation fluid volume, resection time, pre- and post-operative electrolytes, hemoglobin levels taken within 48 hours before and after surgery, and blood transfusion information were collected. In order to establish parameters for post-operative laboratory monitoring, we categorized prostate size, resection time, and irrigation fluid into groups i.e. ( $<45 \mathrm{~g}, 45-60 \mathrm{~g}, 61-80 \mathrm{~g}$ and $>80 \mathrm{~g}),(<30 \mathrm{~min}, 31-60 \mathrm{and}>60 \mathrm{~min})$ and $(<20 \mathrm{~L}, 21-40 \mathrm{~L}$ and $>40$ L) respectively.

Results: A total of 1.000 patients were included. The median age was 66 years with the minimum of 46 years and maximum of 98 years. The median prostate size was $54.26 \mathrm{~g}$. Among all pre- and post-operative laboratory parameters, only hemoglobin and sodium showed a significant change, which were analyzed further. Drop in hemoglobin was significantly associated with increasing prostate size and volume of irrigation fluid. Patients with a prostate size of $>80 \mathrm{~g}$ had 27.3 times higher chance of significant $(>2 \mathrm{~g})$ drop in hemoglobin while 5.1 times higher when irrigation volume exceeded 40 liters. Low levels of sodium were strongly associated with prostate size, irrigation fluid volume, and resection time. However, all these factors become insignificant $(\mathrm{p} \geq 0.05)$ for their effect on low sodium, when these variables were adjusted with each other. Blood transfusion was performed in 27 patients. All these patients belonged to a group of patients with prostate size of more than $80 \mathrm{~g}$ with high resection time and irrigation fluid volume. Three patients had TUR syndrome. Post-operative hemoglobin and electrolytes monitoring contributed to a change in the management of only $14 \%$ of patients.

Conclusion: Routine post-operative hemoglobin and electrolyte measurement is not required in every patient undergoing TURP. Use of risk stratification approach will help us to decide which patient needs post-operative lab testing.
\end{abstract}

Keywords: Transurethral resection of prostate, Post-operative, Hemoglobin, Electrolytes, Benign prostatic hyperplasia

Öz

Amaç: Transüretral prostat rezeksiyonu (TURP) sonrası, hastalarda postoperatif hemoglobin ve elektrolit izleminin önemini değerlendirmek ve izlem için dikkate alınması gereken parametreleri belirlemektir.

Correspondence: Muhammad Hammad Ali Mithani MD, The Kidney Centre Post Graduate Training Institute, Department of Urology, Karachi, Pakistan E-mail: dr.hammad.mithani@gmail.com ORCID-ID: orcid.org/0000-0002-2166-7248

Received: 23.03.2018 Accepted: 12.06.2018

Cite this article as: Mithani MHA, El Khalid S, Khan SA, Sharif I, Awan AS. Is Routine Measurement of Post-operative Hemoglobin and Electrolytes Necessary in Every Patient After Transurethral Resection of the Prostate? J Urol Surg 2018;5(4):157-164.

बCopyright 2018 by the Association of Urological Surgery / Journal of Urological Surgery published by Galenos Publishing House. 
Gereç ve Yöntem: 2007-2017 yılları arasındaki TURP hastalarının verileri gözden geçirildi. Prostat büyüklüğü, irrigasyon sıvısı hacmi, rezeksiyon zamanı, ameliyat öncesi ve sonrası elektrolitler, 48 saatlik hemoglobin seviyeleri ve kan transfüzyonu bilgileri ile ilgili veriler toplandı. Ameliyat sonrası laboratuvar izlemi için parametreler belirlemek amacıyla sırasıyla; prostat büyüklüğü (<45 g, 45-60 g, 61-80 g ve >80 g), rezeksiyon zamanı ( $<30$ dk., 31-60 dk. ve $>60 \mathrm{dk}$.) ve irrigasyon SIvISI $(<20 \mathrm{~L}, 21-40 \mathrm{~L}$ ve $>40 \mathrm{~L}$ ) vb. kategorize edildi.

Bulgular: Çalışmaya toplam 1,000 hasta dahil edildi. Ortalama yaş 66 yıl iken; minimum 46, maksimum 98 yıl idi. Ortalama prostat büyüklüğü 54,26 g idi. Tüm ameliyat öncesi ve sonrası laboratuvar parametreleri arasında sadece hemoglobin ve sodyum anlamlı bir değişim göstermiştir. Hemoglobin düşüşü, prostat büyüklüğünün artması ve irrigasyon sıvısının hacmi ile anlamlı olarak ilişkili idi. Prostat büyüklüğü > $80 \mathrm{~g}$ olan hastalar, hemoglobinde 27,3 (>2 g) kat daha yüksek anlamlı düşüşe sahip iken; irrigasyon hacmi 40 L'yi aştığında bu düşüş 5,1 kat daha yüksek olmuştur. Prostat büyüklüğü, irrigasyon sıvısı hacmi ve rezeksiyon zamanı multinominal lojistik regresyon analizinden sonra düşük sodyum etkisi nedeniyle önemsiz $(\mathrm{p} \geq 0,05)$ hale gelmiştir. Postoperatif hemoglobin ve elektrolit izlemi, hastaların sadece \%14'ünün yönetiminde bir değişikliğe katkıda bulunmuştur.

Sonuç: TURP uygulanan her hastanın, postoperatif rutin hemoglobin ve elektrolit ölçümleri gerekli değildir. Risk sınıflandırma yaklaşımının kullanımı, postoperatif laboratuvar testlerine hangi hastanın ihtiyaç duyduğuna karar vermede bizlere yardımcı olacaktır.

Anahtar Kelimeler: Transüretral prostat rezeksiyonu, Postoperatif, Hemoglobin, Elektrolit, Benign prostat hiperplazisi

\section{Introduction}

Transurethral resection of the prostate (TURP) is one of the most common urological procedures. It has been the gold standard procedure for benign prostatic hyperplasia (BPH) with symptomatic bladder outlet obstruction (B00) (1). Despite introduction of newer procedures, such as holmium laser enucleation, GreenLight laser and diode laser ablation, TURP still retains its position (2). Previously, post-procedure complications occurred quite frequently, with early complications of bleeding, sepsis, electrolytes imbalance, TUR syndrome, incontinence, and urinary retention (3). In the past few decades, there has been considerable decrement in the incidence of these early complications mainly due to standardization of the procedure, and improvement in equipment, perioperative management, and anesthetic techniques (4). Although bleeding is the most important complication of TURP (5), a combined data from 10654 procedures reported that only $2.9 \%$ cases required transfusion due to bleeding (6). Later, it was recommended that routine blood testing was not necessary (7). After bleeding, the next most important complication is electrolyte imbalance, due to the significant risk of developing TUR syndrome (8). However, it has also become rare with time. The risk of developing electrolyte imbalance is less than $1.1 \%$, and this is attributable to a better understanding of its pathophysiology and advances in technology (9).

Despite considerable reduction in complications, major urological associations have not been specified by the guidelines for which patients require post-TURP hemoglobin $(\mathrm{Hb})$ and electrolyte monitoring. Although such testing is performed routinely in many centers, it varies amongst different centers, usually not taking into account risk factors associated with electrolyte imbalance. Routine testing in all patients irrespective of risk factors is costly and burdensome. A study from an academic institute shows that out of a total of 24482 laboratory tests performed in 426 patients admitted for different diseases,
$67.9 \%$ of the tests were irrelevant or unnecessary and the test results did not contribute towards the effective management of the patient (10).

At a time when a practice is both evidence-based and economical, we set out to establish certain parameters that can be considered before going for routine post-operative $\mathrm{Hb}$ and electrolytes measurement.

\section{Materials and Methods}

We retrospectively reviewed data of patients who underwent TURP between 2007 and 2017. The cases were performed by all urologists within the unit. Ethical review committee approval was taken before commencement of the study from the Kidney Centre Ethical Review Committee, under the Auspices of Dorab Patel Post Graduate Training and Research Centre (reference number: 26-UR0-062015). All patients, who had normal preoperative clotting profile and negative urine cultures, were included in the study. Patients excluded were those who were taking diuretics, antithrombotic, and anticoagulant drugs. The pre- and post-operative electrolytes, $\mathrm{Hb}$ levels taken within 48 hours before and after surgery and blood transfusion information were collected from the hospital's medical record department. Information regarding prostate size, irrigation fluid volume and resection time were also collected. A consultant or senior resident under supervision of a consultant carried out TURP using a $26 \mathrm{Fr}$ continuous flow resectoscope with monopolar diathermy. During the procedure, the bladder was irrigated with $1.5 \%$ glycine. After the surgery, $0.9 \%$ saline was used for irrigation.

In order to establish parameters for post-operative laboratory monitoring, variables were categorized into groups. Prostate size was categorized in 3 groups i.e., $<45$ g, 45-60 g, 61-80 and >80 g. Similarly, resection time and irrigation fluid volume were also categorized into 3 groups: ( $<30 \mathrm{~min}, 31-60$ and $>60 \mathrm{~min}$ ) and $(<20 \mathrm{~L}, 21-40 \mathrm{~L}$ and $>40 \mathrm{~L})$. Drop in $\mathrm{Hb}$ was considered mild if $<1$ 
$\mathrm{g} / \mathrm{dL}$, considered moderate and severe if the drop was 1-2 $\mathrm{g} / \mathrm{dL}$ and $>2 \mathrm{~g} / \mathrm{dL}$, respectively. To see electrolyte derangements, postoperative serum sodium and potassium values were analyzed in all groups.

\section{Statistical Analysis}

Data analyses were performed by using software IBM SPSS version 21. Mean and standard deviation were reported for normally distributed continuous variables while for skewed data medians with interquartile range were described. At the stage of inferential analysis, continuous variables were categorized and association was obtained between different variables by the chisquare test. Two predicted model using binary and multinomial logistic regression analyses were established to evaluate the effect of factors leading toward low sodium and drop in $\mathrm{Hb}$. A $p$ value of less than 0.05 was considered statistically significant.

\section{Results}

A total of 1.005 patients had TURP in the study period. Five patients were excluded due to incomplete data. A total of 1.000 patients were included. The median age was 66 years with the minimum of 46 years and maximum of 98 years (Table 1). The median prostate size was $54.26 \mathrm{~g}$. Among all pre- and postoperative laboratory parameters, only $\mathrm{Hb}$ and sodium showed a significant change (Table 2), which were analyzed further. For drop in sodium levels, prostate size, resection time and quantity of irrigation fluid were analyzed with post-operative sodium levels. A prostate size of $>80 \mathrm{~g}(49.6 \%)$, more than 40 liters of irrigation fluid used (50.4\%) and a resection time of longer than 60 minutes (55.8\%) were most strongly associated with low sodium post-operatively (Table 3). On further analysis,

\begin{tabular}{llll}
\hline \multicolumn{4}{l}{ Table 1. Descriptive analysis of clinical variables } \\
\hline & $\begin{array}{c}\text { Median with } \\
\text { IOR }\end{array}$ & Minimum & Maximum \\
\hline Age (years) & 66.13 & 46 & 98 \\
Prostate size (grams) & 54.26 & 34 & 120 \\
Irrigation fluid (liters) & 20.15 & 5 & 60 \\
Resection time (minutes) & 43.30 & 20 & 92 \\
\hline IQR: Interquartile range & & & \\
\hline
\end{tabular}

Table 2. Pre- and post-operative differences of laboratory parameters

\begin{tabular}{lllll}
\hline & $\begin{array}{l}\text { Median } \\
\text { with IQR }\end{array}$ & Minimum & Maximum & $\begin{array}{l}\mathbf{p} \\
\text { value }\end{array}$ \\
\hline $\begin{array}{l}\text { Pre-operative serum } \\
\text { creatinine (mg/dL) }\end{array}$ & $1,0.4$ & 1 & 3 & 0.024 \\
$\begin{array}{l}\text { Post-operative serum } \\
\text { creatinine (mg/dL) }\end{array}$ & $1,0.4$ & 1 & 2 & \\
$\begin{array}{l}\text { Pre-operative } \\
\text { hemoglobin (g/dL) }\end{array}$ & $12.7,2.3$ & 8 & 16 & \\
$\begin{array}{l}\text { Post-operative } \\
\text { hemoglobin (g/dL) }\end{array}$ & $11.8,2.2$ & 7 & 16 & $<0.001$ \\
$\begin{array}{l}\text { Pre-operative } \\
\text { sodium (meq/L) }\end{array}$ & 140,4 & 134 & 150 & \\
$\begin{array}{l}\text { Post-operative } \\
\text { sodium (meq/L) }\end{array}$ & $139,5.7$ & 123 & 148 & $<0.001$ \\
$\begin{array}{l}\text { Pre-operative } \\
\text { potassium (meq/L) }\end{array}$ & $3.9,0.4$ & 3 & 5 & \\
$\begin{array}{l}\text { Post-operative } \\
\text { potassium (meq/L) }\end{array}$ & $3.8,0.5$ & 3 & 6 & \\
\hline \begin{tabular}{l} 
IQR: Interquartile range \\
\hline
\end{tabular} & & & & \\
\hline
\end{tabular}

Table 3. Association of post-operative decrease in sodium with different variables

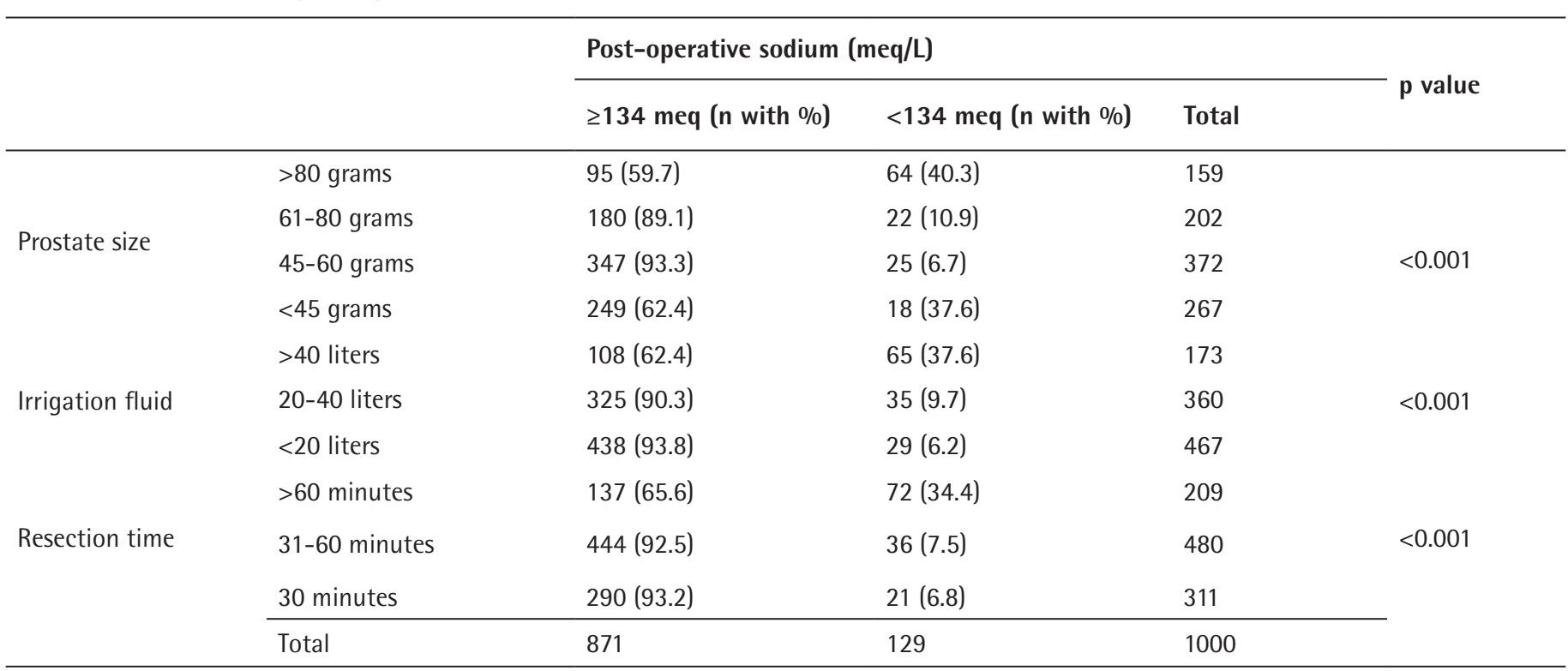


the odds ratio for $>80 \mathrm{~g}$ of size of the prostate was 9.3 times higher than $<45 \mathrm{~g}$ for low sodium $(\mathrm{p}<0.001)$. Similarly, when $>40 \mathrm{~L}$ of irrigation fluid was used, the patients suffered 9.1 times more with low sodium than with the use of $<20 \mathrm{~L}$ of fluid $(p<0.001)$. In the same manner, a resection time of $>60$ minutes was associated with 7.3 times greater risk for low sodium as compared to 30 minutes $(p<0.001)$. When all these variables were adjusted with each other, we found that all these factors become insignificant $(p \geq 0.05)$ for their effect on low sodium (Table 4). For drop in $\mathrm{Hb}$, cross tabulation analysis among four categories of post-operative $\mathrm{Hb}$ drop with different variables was performed. We observed that a $\mathrm{Hb}$ drop of greater than $2 \mathrm{~g}$ was significantly associated with the size of the prostate, quantity of the irrigation fluid used and resection time. 46.3\% of patients with a prostate size $>80 \mathrm{~g}$ had a $\mathrm{Hb}$ drop greater than $2 \mathrm{~g}$ as compared to $4 \%$ in those having $<45 \mathrm{~g}$ of size. On the other hand, $<1 \mathrm{~g}$ drop in $\mathrm{Hb}$ mostly occurred in patients who had a prostate size of $<45 \mathrm{~g}(40.5 \%)$. Similar pattern can be seen with irrigation fluid and resection time (Table 5). On further analysis by multinomial logistic regression analysis, patients with a prostate size of $>80 \mathrm{~g}$ had 62.4 times higher chance of significant (greater than $2 \mathrm{~g}$ ) drop in $\mathrm{Hb}$ while those with a prostate size 61-80 $\mathrm{g}$ and $45-60 \mathrm{~g}$ had 11 times and 8.8 times greater risk, respectively, as compared to those with a prostate size of $<45 \mathrm{~g}(\mathrm{p}<0.001)$. After adjustment of other confounding variables, the risk was reduced but remained

Table 4. Univariable and multivariable binary logistic regression analysis for effects of factors on post-operative serum sodium

\begin{tabular}{|c|c|c|c|c|c|c|c|c|}
\hline \multirow[t]{3}{*}{ Unadjusted analysis } & \multirow{3}{*}{ Odds ratio } & & & \multicolumn{4}{|c|}{ Adjusted analysis } & \multirow{3}{*}{ p valu } \\
\hline & & \multicolumn{2}{|c|}{$95 \%$ Cl for $\exp (\mathrm{B})$} & \multirow[t]{2}{*}{ p value } & \multirow{2}{*}{ Odds ratio } & \multicolumn{2}{|c|}{$95 \% \mathrm{Cl}$ for $\exp (\mathrm{B})$} & \\
\hline & & Lower & Upper & & & Lower & Upper & \\
\hline Prostate size $>80$ grams & 9.3 & 5.3 & 16.5 & $<0.001$ & 3.0 & 0.9 & 10.5 & 0.069 \\
\hline Prostate size $61-80$ grams & 1.7 & 0.9 & 3.2 & 0.114 & 1.3 & 0.5 & 3.0 & 0.59 \\
\hline Prostate size $45-60$ grams & 0.98 & 0.5 & 1.9 & 0.99 & 0.9 & 0.1 & 1.9 & 0.81 \\
\hline Prostate size $<45$ grams & 1.0 & - & - & - & - & - & - & - \\
\hline Irrigation fluid $>40$ liters & 9.1 & 5.6 & 14.8 & $<0.001$ & 1.9 & 0.6 & 6.0 & 0.260 \\
\hline Irrigation fluid 20-40 liters & 1.6 & 1.0 & 2.7 & 0.063 & 1.4 & 0.7 & 2.8 & 0.34 \\
\hline Irrigation fluid $<20$ liters & 1.0 & - & - & - & - & - & - & - \\
\hline Resection time $>60$ minutes & 7.3 & 4.3 & 12.3 & $<0.001$ & 1.7 & 0.6 & 4.9 & 0.360 \\
\hline Resection time $30-60$ minutes & 1.1 & 0.6 & 2.0 & 0.691 & 0.9 & 0.4 & 1.9 & 0.79 \\
\hline Resection time 30 minutes & 1.0 & - & - & - & - & - & - & - \\
\hline
\end{tabular}

Table 5. Association of post-operative hemoglobin drop with different variables

\begin{tabular}{|c|c|c|c|c|c|c|}
\hline & & \multicolumn{4}{|c|}{ Drop in hemoglobin $(\mathrm{g} / \mathrm{dL})$} & \multirow{2}{*}{$p$ value } \\
\hline & & $<1$ gram (n with \%) & 1-2 gram (n with \%) & >2 gram (n with \%) & Total & \\
\hline \multirow{4}{*}{ Prostate size } & $>80$ grams & $40(25.2)$ & 509 (31.4) & $69(46.3)$ & 159 & \multirow{4}{*}{$<0.001$} \\
\hline & $61-80$ grams & $95(47)$ & $78(38.6)$ & $29(14.4)$ & 202 & \\
\hline & 45-60 grams & $184(49.5)$ & $143(38.4)$ & $45(12.1)$ & 372 & \\
\hline & $<45$ grams & $217(81.3)$ & $44(16.5)$ & $6(2.2)$ & 267 & \\
\hline \multirow{3}{*}{ Irrigation fluid } & $>40$ liters & $42(24.2)$ & $61(35.3)$ & $70(40.5)$ & 173 & \multirow{3}{*}{$<0.001$} \\
\hline & 20-40 liters & $164(45.6)$ & $147(40.8)$ & $49(13.6)$ & 360 & \\
\hline & $<20$ liters & $330(70.7)$ & $107(22.9)$ & $30(6.4)$ & 467 & \\
\hline \multirow{4}{*}{ Resection time } & $>60$ minutes & $61(29.2)$ & 79 (37.8) & $69(33)$ & 209 & \multirow{4}{*}{$<0.001$} \\
\hline & $31-60$ minutes & $235(49)$ & $179(37.3)$ & $66(13.8)$ & 480 & \\
\hline & 30 minutes & $240(49)$ & 57 (18.3) & $14(4.5)$ & 311 & \\
\hline & Total & 536 & 315 & 149 & 1000 & \\
\hline
\end{tabular}


significantly higher at 27.3, 6.7 and 6.1 times, respectively (Table 6). Figure 1 shows the mean $\mathrm{Hb}$ drop with the increase in the size of the prostate. Regarding resection time, a significant drop $(>2 \mathrm{~g})$ in $\mathrm{Hb}$ occurred, in those patients with resection time $>60$ minutes $(p<0.001)$ as compared to those with 30 minutes (19.4 times more). However, the effect of resection time on $\mathrm{Hb}$ drop became insignificant when adjusted with other variables $(p \geq 0.05)$. On the other hand, the volume of irrigation fluid for significant drop ( $>2 \mathrm{~g}$ ) in $\mathrm{Hb}$ remained significant even after adjustment of confounding variables. The adjusted odds ratio decreased from 18.3 times to 5.1 times for $>40$ liters (Table 6). Out of 1000 patients, blood transfusion was done in 27 patients, and $11 \%$ of patients, who needed further treatment like water restriction and diuretic therapy, had low sodium levels postoperatively. Three patients developed TUR syndrome. Therefore, post-operative $\mathrm{Hb}$ and electrolyte monitoring contributed to a change in the management of only $14 \%$ of patients. All these patients belonged to a group of patients with a prostate size of more than $80 \mathrm{~g}$, long resection time and high irrigation fluid volume. Considering these results, a more practical risk stratification approach is suggested (Table 7).

\section{Discussion}

TURP is the gold standard surgical treatment for patients with moderate to severe lower urinary tract symptoms associated with $\mathrm{BPH}$, and is most effective in relieving BOO due to large prostate size (11). Although perioperative mortality and morbidity rates have declined over time, they still remain at $0.1 \%$ and $11.1 \%$, respectively, mainly due to bleeding, acute kidney injury, and TUR syndrome $(12,13)$.

Table 6. Univariable and multivariable multinomial logistic regression analysis for effect of factors on drop in hemoglobin after surgery

Unadjusted multinomial analysis

\begin{tabular}{|c|c|c|c|c|c|c|c|c|c|}
\hline \multirow{2}{*}{$\begin{array}{l}\text { Drop in } \\
\text { hemoglobin }\end{array}$} & & \multirow{2}{*}{$\begin{array}{l}\text { Odds } \\
\text { ratio }\end{array}$} & \multicolumn{2}{|c|}{$\begin{array}{l}\text { 95\% confidence } \\
\text { interval for } \exp (\mathrm{B})\end{array}$} & \multirow{2}{*}{$p$ value } & \multirow{2}{*}{$\begin{array}{l}\text { Odds } \\
\text { ratio }\end{array}$} & \multicolumn{2}{|c|}{$\begin{array}{l}95 \% \text { confidence } \\
\text { interval for } \exp (B)\end{array}$} & \multirow{2}{*}{$p$ value } \\
\hline & & & $\begin{array}{l}\text { Lower } \\
\text { bound }\end{array}$ & $\begin{array}{l}\text { Upper } \\
\text { bound }\end{array}$ & & & $\begin{array}{l}\text { Lower } \\
\text { bound }\end{array}$ & $\begin{array}{l}\text { Upper } \\
\text { bound }\end{array}$ & \\
\hline \multirow{3}{*}{$1-2$ gram } & Prostate size $>80$ grams & 6.2 & 3.6 & 10.4 & $<0.001$ & 1.1 & 0.39 & 3.16 & 0.85 \\
\hline & Prostate size $45-60$ grams & 3.8 & 2.6 & 6.3 & $<0.001$ & 2.5 & 1.6 & 3.9 & $<0.001$ \\
\hline & Prostate size $<45$ grams & 1.0 & - & - & - & - & - & - & - \\
\hline \multirow{2}{*}{$>2$ gram } & Prostate size $>80$ grams & 62.4 & 25.4 & 153.2 & $<0.001$ & 27.3 & 5.8 & 129.0 & $<0.001$ \\
\hline & Prostate size $61-80$ grams & 11.0 & 4.4 & 27.5 & $<0.001$ & 6.7 & 2.4 & 18.5 & $<0.001$ \\
\hline \multirow[t]{2}{*}{$1-2$ gram } & $\begin{array}{l}\text { Resection time } 31-60 \\
\text { minutes }\end{array}$ & 3.2 & 2.3 & 4.5 & $<0.001$ & 1.6 & 1.1 & 2.5 & 0.047 \\
\hline & Resection time 30 minutes & 1.0 & - & - & - & - & - & - & - \\
\hline \multirow{3}{*}{$>2$ gram } & Resection time $>60$ minutes & 19.4 & 10.2 & 36.8 & $<0.001$ & 0.6 & 0.2 & 1.9 & 0.350 \\
\hline & $\begin{array}{l}\text { Resection time } 31-60 \\
\text { minutes }\end{array}$ & 4.8 & 2.6 & 8.8 & $<0.001$ & 1.5 & 0.7 & 3.1 & 0.28 \\
\hline & Resection time 30 minutes & 1.0 & - & - & - & - & - & - & - \\
\hline 1-2 gram & Irrigation fluid $>40$ liters & 4.5 & 2.9 & 7.0 & $<0.001$ & 3.7 & 1.4 & 9.4 & 0.007 \\
\hline
\end{tabular}

Adjusted multinomial analysis

The reference category is: $<1$ gram 


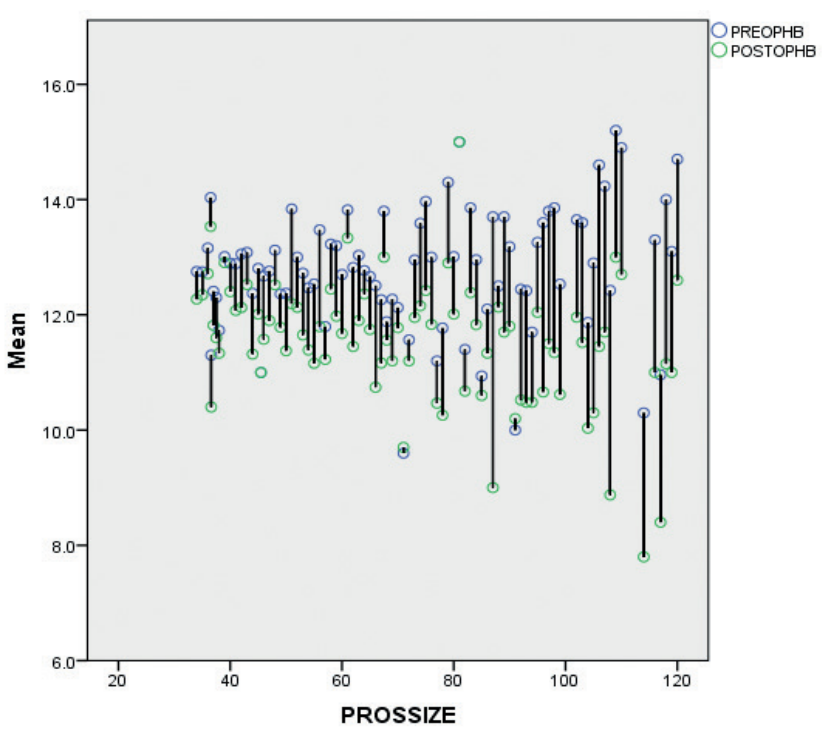

Figure 1. Change in mean hemoglobin pre- and post-transurethral resection of the prostate in relation to prostate size

PREOPHB: Preoperative hemoglobin, POSTOPHB: Postoperative hemoglobin, PROSSIZE: Prostate size

\begin{tabular}{ll}
\hline Table 7. Risk stratification strategy \\
\hline Low risk group & $\begin{array}{l}\text { Post-operative } \mathrm{Hb} \text { and } \\
\text { electrolytes monitoring not } \\
\text { required }\end{array}$ \\
Prostate size: $<45 \mathrm{~mL}$ & $\begin{array}{l}\text { Post-operative } \mathrm{Hb} \text { and } \\
\text { electrolytes monitoring is } \\
\text { optional. Consider age, comorbid, } \\
\text { and general condition of patients }\end{array}$ \\
Intermediate group & $\begin{array}{l}\text { Post-operative Hb and } \\
\text { electrolytes monitoring should } \\
\text { be done in all cases }\end{array}$ \\
High risk group & \\
Resection time $>60 \mathrm{minutes}$ & $\mathrm{mL}$ \\
Irrigation fluid $>40 \mathrm{~L}$ & \\
Prostate size $>80 \mathrm{~mL}$ & \\
\hline Hb: Hemoglobin &
\end{tabular}

Bleeding has many contributing factors, which include acetylsalicylic acid intake, activation of fibrinolysis system, size of the prostate gland, weight of the resected gland, duration of the procedure, histologic presentation of the gland, and presence of urinary tract infection $(14,15)$.

Regarding irrigation fluid used during TURP, it has been proven that $1.5 \%$ glycine and $2.7 \%$ sorbitol have not shown significant impact on the result (16). Therefore, glycine $1.5 \%$ was used in the present study. A resection time of longer than 60 minutes was related to an increase in loss of blood in two studies (17), but was refuted by another study (18). Mebust (19) has reported that the incidence of blood loss was higher in patients with a resected prostate tissue greater than $45 \mathrm{~g}$. In this study, blood loss was also strongly associated with prostate size. The mean change in $\mathrm{Hb}$ in our study was $0.9 \mathrm{~g} / \mathrm{dL}$, which appears to be slightly lower as compared to other studies (20).

Studies have used different methods for estimating blood loss after TURP, but these require additional resources and hence have added costs and a margin of error of $4-5 \%(20,21)$. PostTURP, maximum blood loss occurs within 2 days, with time to $50 \%$ blood loss at 16 hours. Hence, testing of $\mathrm{Hb}$ levels within 48 hours TURP is a practical and widely used method of determining blood loss (22). Although post-operative $\mathrm{Hb}$ is a useful guide to the need for transfusion and it is included in the TURP integrated care pathway at many centers, but routine testing of post-operative $\mathrm{Hb}$ in every patient is questionable. Often these results are overlooked or not documented, as discovered during this study. In addition, unnecessary blood testing raises ethical concern and discomfort to the patient. This testing should only be done where indicated, as in patients with large vascular glands, who have undergone long resections, ongoing blood loss or symptomatic anemia.

Another important complication of TURP is electrolyte imbalance. This includes TUR syndrome. The amount of fluid absorbed is directly related to the number and size of opened venous sinuses. This hypervolemic hyponatremic state may lead to mental confusion, bradycardia, hypertension, nausea, vomiting, and visual disturbances associated with hyponatremia (23).

Recent advancements in technology and with better understanding of pathophysiology, TUR syndrome has become a rare condition (less than 1.1\%). These include development of continuous flow resectoscopes, utilization of non-hemolytic solutions, such as glycine, sorbitol, and mannitol, limited resection time and advances in training techniques $(9,24)$. Hydrostatic pressure at the prostatic bed is an important factor for fluid absorption during TURP. This is dependent on the height of irrigating fluid column, and pressure inside the bladder during surgery (25). For good vision during resection, $60 \mathrm{~cm}$ is the suggested ideal height of irrigating fluid to obtain around $300 \mathrm{~g}$ of fluid per minute. In this study, the irrigation fluid column height was constant so that other determinants could be assessed.

In patients with deranged electrolytes, a higher volume of irrigant was found to be used in previous studies (26). Several proposed strategies are present for reduction in risk of fluid absorption during TURP, but none has been completely successful. Resection time is suggested to be kept below 60 min for minimal fluid absorption (27). In our study, three patients developed clinical TUR syndrome (0.3\%), and the value of $<135 \mathrm{mEq} / \mathrm{L}$ was used to define hyponatremia. In relation to potassium, post-operative hyperkalemia may result due to cell lysis and release of intracellular potassium, or due to acute 
kidney injury secondary to sepsis or obstruction. A significant change in serum potassium levels was not encountered postoperatively, which can be explained by the fact that absorption of irrigation fluid causes hemodilution and offsets any changes in potassium. Also with the use of $1.5 \%$ glycine as an irrigant, hemolysis is comparatively minimal (28). Few studies have investigated the usefulness of routine electrolyte testing following TURP (29). Most of them focused on post-TURP $\mathrm{Hb}$ monitoring (30). It was concluded that post-operatively, routine blood testing is unnecessary and should only be sought on clinical need or after technically demanding surgery. Newer techniques, such as bipolar resectoscopes and vaporizing of tissue instead of resection, have caused reduction in absorption of fluid and hence electrolyte imbalance. Therefore, routine monitoring of fluid absorption has been abandoned in many hospitals. However, no guideline on routine monitoring of postoperative electrolytes is present. It has been shown in this study that post-operative $\mathrm{Hb}$ and electrolyte monitoring contributed to a change in the management of only $14 \%$ of patients as only $2.7 \%$ patients needed blood transfusion and $11 \%$ patients needed treatment for hyponatremia. Therefore, routine $\mathrm{Hb}$ and electrolyte measurements post-operatively are not required in every patient.

In view of the above findings, a more practical approach is suggested. A risk stratification strategy should be implemented, which will help decide which patients need post-operative lab testing. As a result, elimination of unnecessary investigations will be more cost effective and comfortable for patients.

\section{Study Limitations}

There are a few limitations in this study. As this is a retrospective study, information related to resected volume of the prostate was not available. Lack of uniformity in terms of expertise of different surgeons was another limitation.

\section{Conclusion}

Routine $\mathrm{Hb}$ and electrolyte measurements post-operatively are not required in every patient. Use of risk stratification approach will help us decide which patient needs post-operative lab testing.

\section{Ethics}

Ethics Committee Approval: Ethical review committee approval was taken before commencement of this study from the Kidney Centre Ethical Review Committee, Under the Auspices of Dorab Patel Post Graduate Training and Research Centre (reference number: 26-URO-062015).

Informed Consent: Retrospective study.

Peer-review: Externally peer-reviewed.

\section{Authorship Contributions}

Surgical and Medical Practices: M.H.A.M., S.E.K., Concept: M.H.A.M., Design: M.H.A.M., Data Collection or Processing: M.H.A.M., S.A.K., I.S., A.S.A., Analysis or Interpretation: M.H.A.M., S.A.K., I.S., Literature Search: M.H.A.M., S.E.K., A.S.A., Writing: M.H.A.M., S.E.K.

Conflict of Interest: No conflict of interest was declared by the authors.

Financial Disclosure: The authors declared that this study received no financial support.

\section{References}

1. Lynch $\mathrm{M}$, Anson $\mathrm{K}$. Time to rebrand transurethral resection of the prostate? Curr Opin Urol 2006;16:20-24.

2. Lourenco T, Pickard R, Vale L, Grant A, Fraser C, MacLennan G, N'Dow J; Bening Prostatic Enlargement team. Minimally invasive treatments for benign prostatic enlargement: systematic review of randomised controlled trials. BMJ 2008;337:a1662.

3. Ather MH, Faruqui N, Abid F. Optimization of low pre-operative hemoglobin reduces transfusion requirement in patients undergoing transurethral resection of prostate. J Park Med Assoc 2003;53:104-106.

4. Teo JS, Lee YM, Ho HSS. An update on transurethral surgery for benign prostatic obstruction. Asian J Urol 2017;4:195-198.

5. Mebust WK, Holtgrewe HL, Cockett AT, Peters PC. Transurethral prostatectomy: immediate and postoperative complications. A cooperative study of 13 participating institutions evaluating 3,885 patients. J Urol 1989;141:243-247.

6. Reich O, Gratzke C, Bachmann A, Seitz M, Schlenker B, Hermanek P, Lack $N$, Stief CG; Urology Section of the Bavarin Working Group for Quality Assurance. Morbidity, mortality and early outcome of transurethral resection of the prostate: a prospective multicenter evaluation of 10,654 patients. J Urol 2008;180:246-249.

7. Fraser I, Scott M, Campbell I, Wood JK, Smart JG, Osborn DE. Routine crossmatching is not necessary for a transurethral resection of the prostate. $\mathrm{Br}$ J Urol 1984;56:198-201.

8. Muhammad AT, Shaikh AA, Devrajani BR, Shah ZA, Das T, Singh D. Serum sodium level in transurethral resection of the prostate (TURP) (a cross sectional descriptive study at two hospitals. Medical Channel 2010;16:218220.

9. Hawary A, Mukhtar K, Sinclair A, Pearce I. Transurethral resection of the prostate syndrome: almost gone but not forgotten. J Endourol 2009;23:2013-2020.

10. Miyakis S, Karamanof G, Liontos M, Mountokalakis TD. Factors contributing to inappropriate ordering of tests in an academic medical department and the effect of an educational feedback strategy. Postgrad Med J 2006;82:823-829.

11. Chisholm GD. Benign prostatic hyperplasia: the best treatment. BMJ 1989;299:215-216.

12. Rassweiler J, Teber D, Kuntz R, Hofmann R. Complications of transurethral resection of the prostate (TURP)--incidence, management, and prevention. Eur Urol 2006;50:969-979.

13. Mamoulakis C, Efthimiou I, Kazoulis S, Christoulakis I, Sofras F. The modified Clavien classification system: a standardized platform for reporting complications in transurethral resection of the prostate. World J Urol 2011;29:205-210. 
14. Watson CJ, Deane AM, Doyle PT, Bullock KN. Identifiable factors in postprostatectomy haemorrhage: the role of aspirin. BJU 1990;66:85-87.

15. Smyth R, Cheng D, Asokumar B, Chung F. Coagulopathies in patients after transurethral resection of the prostate: spinal versus general anesthesia. Anesth Analg 1995;81:680-685.

16. Inman RD, Hussain Z, Elves AW, Hallworth MJ, Jones PW, Coppinger SW. A comparison of $1.5 \%$ glycine and $2.7 \%$ sorbitol- $0.5 \%$ mannitol irrigants during transurethral prostate resection. J Urol 2001;166:2216-2220.

17. Kirollos MM, Campbell N. Factors influencing blood loss in transurethral resection of the prostate (TURP): auditing TURP. Br J Urol 1997;80:111-115.

18. Nielsen KK, Andersen K, Asbjørn J, Vork F, Ohrt-Nissen A. Blood loss in transurethral prostatectomy: epidural versus general anaesthesia. Int Urol Nephrol 1987;19:287-292.

19. Mebust WK. Transurethral prostatectomy. Urol Clin North Am 1990;17:575585.

20. Abrams PH, Shah PJ, Bryning K, Gaches CG, Ashken MH, Green NA. Blood loss during transurethral resection of the prostate. Anaesthesia 1982;37:7173.

21. Freedman M, Van der Molen SW, Makings E. Blood loss measurement during transurethral resection of the prostate gland. Br J Urol 1985;57:311-316.

22. Lewi HJ, Hales DS, Mahmoud S, Scott R. The characteristics of post TUR blood loss: a preliminary study. Urol Res 1983;11:29-31.
23. Vijayan S. TURP syndrome. Trends in Anaesthesia and Critical Care 2011;1:46-50.

24. Mamoulakis C, Skolarikos A, Schulze M, Scoffone CM, Rassweiler JJ, Alivizatos G, Scarpa RM, de la Rosette JJ. Results from an international multicenter double-blind randomized controlled trial on the perioperative efficacy and safety of bipolar vs monopolar transurethral resection of the prostate. BJU Int 2012;109:240-248.

25. Madsen PO, Naber KG. The importance of the pressure in the prostatic fossa and absorption of irrigating fluid during transurethral resection of the prostate. J Urol 1973;109:446-452.

26. Gupta K, Rastogi B, Jain M, Gupta PK, Sharma D. Electrolyte changes: An indirect method to assess irrigation fluid absorption complications during transurethral resection of prostate: A prospective study. Saudi J Anaesth 2010;4:142-146.

27. Hurlbert BJ, Wingard DW. Water intoxication after 15 minutes of transurethral resection of the prostate. Anesthesiology 1979;50:355-356.

28. Moorthy HK, Philip S. Serum electrolytes in TURP syndrome--is the role of potassium under-estimated? Indian J Anaesth 2002;46:441-444.

29. Hakeem AR, Sairam K, Plail OR. The Value of Blood Tests Following Transurethral Resection of the Prostate. UIJ. 2009:2.

30. Shah J, Nethercliffe J. Is routine post-operative hemoglobin measurement required after transurethral resection of prostate? Transfus Med 2004;14:343-346. 